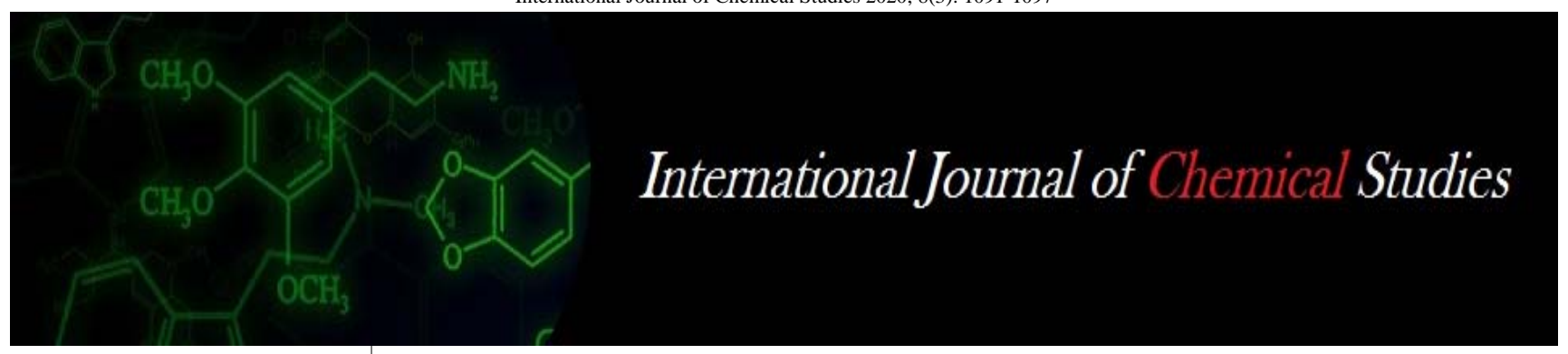

P-ISSN: 2349-8528 E-ISSN: 2321-4902 www.chemijournal.com IJCS 2020; 8(3): 1091-1097 (C) 2020 IJCS

Received: 19-03-2020 Accepted: 21-04-2020

Priyanka Jena

Department of fruit science and horticulture technology,

Orissa University of agriculture and technology, Bhubaneswar, Odisha, India

Saudamini Swain All India coordinated research project on fruits (Banana), Orissa University of agriculture and technology, Bhubaneswar. Odisha, India

Bipin Kumar Pradhan All India coordinated research project on fruits (Banana), Orissa University of agriculture and technology, Bhubaneswar, Odisha, India

Pragyanshree Priyadarshinee Sahu

Department of fruit science and horticulture technology,

Orissa University of agriculture and technology, Bhubaneswar, Odisha, India

Soumya Rath

Department of fruit science and horticulture technology, Orissa University of agriculture and technology, Bhubaneswar, Odisha, India
Corresponding Author: Priyanka Jena Department of fruit science and horticulture technology, Orissa University of agriculture and technology, Bhubaneswar, Odisha, India

\section{Evaluation of new banana (Musa spp.) genotypes under Odisha conditions}

\author{
Priyanka Jena, Saudamini Swain, Bipin Kumar Pradhan, Pragyanshree \\ Priyadarshinee Sahu and Soumya Rath
}

DOI: https://doi.org/10.22271/chemi.2020.v8.i3n.9345

\begin{abstract}
The present study was undertaken to evaluate five cultivars of banana (Musa sp.) belonging to different genomic groups (AAB and $\mathrm{ABB}$ ) for growth, yield and quality attributes. From the evaluation of the data for growth, yield and quality parameters, it was evident that among all the genotypes, the maximum pseudostem height $(352.3 \mathrm{~cm})$ was recorded in Budubale, whereas, NRCB Selection-10 recorded the highest pseudostem girth $(69.4 \mathrm{~cm})$, number of suckers (8.6), and number of functional leaves (14.6) at shooting stage. The earliest shooting and fruit maturity (216.1 and 297.4 days respectively) were observed in BRS Selection Popoulu, whereas, late shooting and fruit maturity (289.6 and 390.1days respectively) were recorded in Budubale. Regarding yield attributes, the maximum bunch weight (20.4 $\mathrm{Kg}$ ), bunch length (66.6 cm), number of hands per bunch (12.1), number of fingers per bunch (171.2) and yield per hectare (51 tonnes) were recorded in genotype NRCB Selection-10. However, bunch girth $(160.1 \mathrm{~cm})$, finger girth $(20.0 \mathrm{~cm})$ and weight of finger $(264.6 \mathrm{~g})$ were highest in BRS Selection Popoulu. In the AAB genomic group, Popoulu and Manjeri Nendran registered $62.13 \%$ and $34.45 \%$ yield increase over the check Nendran respectively. In the ABB genomic group, NRCB Selection-10 recorded $40.68 \%$ yield increase over the check Budubale. With respect to the quality parameters like TSS, reducing sugar and total sugar content, the genotype, Manjeri Nendran was found to be superior among all the genotypes. On the basis of results obtained in the present investigation, NRCB Selection-10 recorded the highest yield which was at par with BRS Selection Popoulu. The maximum net return of Rs. 392000/ha and B:C ratio of 2.78 was recorded in NRCB Selection-10 against the B:C ratio of 1.89 in BRS Selection Popoulu.
\end{abstract}

Keywords: Banana, randomized block design, yield attributing characters

\section{Introduction}

Banana (Musa spp.) is a herbaceous perennial monocotyledonous plant which belongs to the family Musaceae of order Scitamineae. It is the largest produced and consumed amongst all fruits cultivated in India. It is a crop of subsistence being cultivated from prehistoric time in India with great socio-economic significance and is grown in all tropical regions. It provides well balanced diet to millions of people around the globe and also contributes to livelihood through crop production, processing (Singh, 2002) ${ }^{[30]}$ and thus, plays a key role in the economy of many developing countries.

The term "banana" was introduced from the Guinea coast of West Africa by the Portuguese, while the term "plantain" (cooking bananas) was derived from "plantano" of the Spaniards

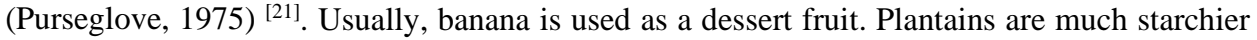
and generally used for culinary purpose. Plantain and cooking bananas are staple food of people of many countries of Central and West Africa, the Caribbean Islands and Latin America. Ripe bananas are easily digestible food with high nutritive value. There are probably over 30 well known species and more than 700 varieties within the genus Musa. Simmonds (1962) ${ }^{[29]}$ concluded that almost all modern edible parthenocarpic banana cultivars were evolved by hybridization of two ancestral parents, Musa acuminata and Musa balbisiana, which are considered as the main contributors of $\mathrm{A}$ and $\mathrm{B}$ genomes respectively. All cultivars are classified into various genomic groups such as $\mathrm{AA}, \mathrm{AAA}, \mathrm{AB}, \mathrm{AAB}, \mathrm{ABB}, \mathrm{AAAA}$, AAAB, ABBB etc. based on morphological scoring (Stover and Simmonds, 1987) ${ }^{[31]}$.

Banana is originated from South East Asia, a region considered as the primary centre of diversification of the crop, where early domestication has occurred (Simmonds, 1962) ${ }^{[29]}$. 
In India, banana is appropriately referred as 'Kalpatharu', a plant of all virtues as each and every part of the plant is used for specific purposes. Apart from its use as a dessert fruit and for culinary purposes, the banana plant has multifaceted uses: the leaf is commonly used as a hygienic dining plate and has gained popularity in south India, where varieties are grown commercially for leaves; the male flower is a favourite vegetable; the inner core of the pseudostem is a popular vegetable with many therapeutic uses; the sap is used as an indelible ink in industry etc. Increase in banana cultivation results in abundance of waste materials. These contain cellulose, hemicellulose and lignin which support the growth of edible fungi. Biotransformation of pseudostem and leaves into protein using edible fungi such as Pleurotus sajor-caju for obtaining a protein rich animal feed has been reported. Besides being suitable for composting, banana pseudostem is a suitable raw material for biogas production than cow dung. Banana pseudostem is a good source of fibre with numerous uses including manufacture of ropes, recycled paper, fabric and a variety of handicrafts.

In India, banana is well adopted in the regions varying from humid tropics to humid sub-tropics and semi-arid sub-tropics, and up to 2,000 m above mean sea level. Among horticultural crops, contribution of banana to agricultural Gross Domestic Product (GDP) is the highest (1.99\%). Interesting feature observed in the country is that commercial banana production is largely concentrated along the rivers. In Bihar, it is grown in Gangetic plains, while in Tamil Nadu; major concentration is in Cauvery basin. In Andhra Pradesh, concentration of production is around the Godavari. In Maharashtra, it is more concentrated around the Tapti River. This phenomenon is attributed to soil and availability of water. However, its cultivation has also been extended to areas where water sources have been created. Banana has assumed more significance now-a-days, as it is the source of regular income for small and marginal farmers, and responds very well to crop management system.

Banana is considered as the most auspicious plant and the fruits are used for offering to Hindu Deities. From the nutritional point of view, banana has a calorific value ranging from 67 to 137 calories per $100 \mathrm{~g}$ and is closely comparable with potatoes but digested more easily. It is relatively cheap. According to Gopalan et al. (1980), the average composition of banana fruit is moisture-70\%, protein-1.2\%, carbohydrate$27.0 \%$, crude fibre- $0.5 \%$, fat- $0.3 \%$, ash- $0.9 \%$, phosphorus290.0 ppm, calcium-80.0 ppm, iron-6.0 ppm, carotene-0.5 ppm, riboflavin- 0.5 ppm, niacin-7 ppm, ascorbic acid-120 ppm. There are traces of potassium, copper, iodine, manganese, magnesium, sodium, zinc and cobalt as well.

India is the largest producer of banana contributing $27 \%$ of world production (FAO, 2009) ${ }^{[7]}$. In India, the total area under banana cultivation is 0.85 mha with the production of 30 MT and productivity is about 34.0 MT/ha (NHB, 2016-17) [19]. In Odisha, the total area under banana cultivation is about 24490 ha with the production of around 0.466 MT and productivity is about 19.05 MT/ha (NHB, 2016-17) ${ }^{[19]}$.

The banana cultivars like BRS Selection Popoulu, Nendran and Manjeri Nendran which belong to the genomic group AAB and NRCB Selection-10, Budubale which belong to the genomic group $\mathrm{ABB}$ are all used for dessert purpose. Besides, BRS Selection Popoulu, Nendran and Manjeri Nendran are good source for making chips and very popular in the district of Kerala.

\section{Materials and methods}

The present investigation was carried out at AICRP on Fruits (Banana) located in Horticultural Research Station, OUAT, Bhubaneswar during 2017-18. In the field experiment, five banana genotypes belonging to $\mathrm{AAB}$ and $\mathrm{ABB}$ genomic groups were evaluated. In AAB group, BRS Selection Popoulu and Manjeri Nendran were evaluated against the check Nendran and in ABB group, NRCB Selection-10 was evaluated against the check Budubale. The experiment was conducted in randomized block design with four replications. The plants were spced at $2 \times 2 \mathrm{~m}$ and data on growth, duration, yield and quality attributes were recorded and statistically analyzed.

\section{Results and Discussions}

Banana is one of the most important fruit crops of India as well as Odisha. It could be considered as poor man's apple and it is the cheapest among all other fruits in the country. The present investigation was undertaken to evaluate the new banana genotypes belonging to AAB Plantain type and ABB Karpuravalli type. In AAB plantain type BRS Selection Popoulu, Manjeri Nendran were evaluated against the check Nendran and in ABB Karpuravalli group, NRCB Selection-10 was evaluated against the check Budubale. Their performances were evaluated under the coastal plain zone of Odisha in respect of growth, yield and yield attributing characters and quality parameters. The objective is to select the elite genotypes so that the genotypes could be commercially grown in the farmer's field. The results obtained in the present investigation were discussed under appropriate headings.

\section{Growth attributes}

Significant variation was observed among the five banana genotypes with respect to growth characters. It is evident from the data (table 1) that the maximum pseudostem height was observed in Budubale $(352.30 \mathrm{~cm})$ and the minimum height was recorded in NRCB Selection-10 (210.30 cm). NRCB Selection-10 recorded maximum pseudostem girth $(69.4 \mathrm{~cm})$, whereas, minimum girth was observed in Nendran (50.50 $\mathrm{cm})$. The number of functional leaves at shooting stage was highest in NRCB Selection-10 (14.6) followed by BRS Selection Popoulu (12.7) and Manjeri Nendran (12.1), whereas, lowest in Nendran (9.9). The differences in the plant height stem girth and number of leaves of the plants at the time of shooting has been reported earlier by different workers. It may be attributed to the genetic potential of the plants and environmental factors such as climate and nutrient availability. Kavitha et al. (2009) ${ }^{[10]}$ studied 12 Nendran ecotypes of banana and recorded the range of the plant height from 264.1-387.0 cm. Singh (2010) observed plant height $(2.16 \mathrm{~m})$ in banana cv. Nendran. Menon et al. (2014) ${ }^{[17]}$ recorded pseudostem height of $295.6 \mathrm{~cm}$ in Popoulu and $301.0 \mathrm{~cm}$ in Nendran. They also observed pseudostem girth of $51.6 \mathrm{~cm}$ in Popoulu and $50.6 \mathrm{~cm}$ in Nendran. The number of leaves was significantly higher in BRS Selection Popoulu (12.4) as compared to Nendran (9.8). Present findings are also in conformity with the results obtained by Deo et al. (1999) ${ }^{\text {[5] }}$, Suvittawat et al. (2014) ${ }^{[32]}$, Biswal et al. (2004) ${ }^{[2]}$, Sarkar et al. (2005) ${ }^{[27]}$, Uazire et al. (2008) ${ }^{[34]}$ and Kumar et al. (2012). With respect to phyllochron, the highest reading was observed in Nendran followed by BRS Selection Popoulu, Manjeri Nendran and Budubale and minimum in NRCB Selection-10. Among all the treatments, the maximum leaf length was reported in BRS Selection Popoulu $(148.00 \mathrm{~cm})$. 
NRCB Selection-10 $(65.00 \mathrm{~cm})$ recorded significantly higher leaf width as compared to rest of the genotypes. The leaf area was found to be highest in NRCB Selection-10 $\left(0.70 \mathrm{~m}^{2}\right)$ and least area was found in Manjeri Nendran $\left(0.49 \mathrm{~m}^{2}\right)$. Karuna and Rao (2016) ${ }^{[9]}$ reported similar findings in most of the genotypes. NRCB Selection-10 recorded the maximum number of suckers (8.6), whereas, BRS Selection Popoulu recorded minimum number of suckers (3.4). The number of suckers varied among all the genotypes. The variation in production of sucker was due to varietal characters and production of more suckers absorbs a lot of nutrients from the soil which affects the productivity of the plant. Variability in sucker production among different culinary cultivars was also reported by Biswal et al. (2004) ${ }^{[2]}$ and Blomme et al. (2000) [3].
Days to shooting and harvesting:

In crop duration of different banana genotypes (presented in Fig. 1), early shooting was observed in BRS Selection Popoulu (216.1 days), whereas, late shooting was recorded in Budubale (289.6 days). The same trend was also observed in days taken to harvest. Von Loesecke (1950), Simmonds (1959) ${ }^{[28]}$ and Sanchez (1971) ${ }^{[26]}$ reported the influence of varietal characters and growing conditions on the time taken for flowering in banana. Similar variations were also reported by Ram et al. (1989) ${ }^{[24]}$, Medhi (1994) ${ }^{[16]}$, Deshmukh et al. (2004) ${ }^{[6]}$, Delvadia et al. (2008) ${ }^{[4]}$, Kumar et al. (2012) ${ }^{[12]}$ and Suvittawat et al. (2014) ${ }^{[32]}$.

Table 1: Performance of banana genotypes w.r.t growth attributes

\begin{tabular}{|c|c|c|c|c|c|c|c|c|}
\hline Treatments & $\begin{array}{c}\text { Pseudostem } \\
\text { height at } \\
\text { shooting (cm) }\end{array}$ & $\begin{array}{l}\text { Pseudostem girth } \\
\text { at shooting }(\mathrm{cm})\end{array}$ & $\begin{array}{c}\text { Number of } \\
\text { suckers at } \\
\text { shooting }\end{array}$ & $\begin{array}{c}\begin{array}{c}\text { Number of } \\
\text { functional leaves } \\
\text { at shooting }\end{array} \\
\end{array}$ & $\begin{array}{l}\text { Phyllochron } \\
\text { (in days) }\end{array}$ & \begin{tabular}{|c|c} 
Length of \\
leaves at \\
shooting (cm)
\end{tabular} & \begin{tabular}{|c|}
$\begin{array}{c}\text { Width of } \\
\text { leaves at } \\
\text { shooting }(\mathrm{cm})\end{array}$ \\
\end{tabular} & \begin{tabular}{|c}
$\begin{array}{c}\text { Leaf area at } \\
\text { shooting } \\
\left(\mathbf{m}^{2}\right)\end{array}$ \\
\end{tabular} \\
\hline \multicolumn{9}{|c|}{ AAB (Plantain group) } \\
\hline \begin{tabular}{|c|}
$\begin{array}{c}T_{1}-\text { BRS Selection } \\
\text { Popoulu }\end{array}$ \\
\end{tabular} & 260.6 & 53.5 & 3.4 & 12.7 & 8.1 & 148.00 & 57.60 & 0.68 \\
\hline $\begin{array}{c}\mathrm{T}_{2} \text { - Manjeri } \\
\text { Nendran }\end{array}$ & 305.4 & 57.5 & 4.2 & 12.1 & 7.5 & 116.65 & 51.59 & 0.49 \\
\hline $\begin{array}{l}\text { T3- Nendran } \\
\text { (Check) }\end{array}$ & 297.4 & 50.5 & 6.6 & 9.9 & 8.2 & 144.00 & 54.30 & 0.62 \\
\hline \multicolumn{9}{|c|}{ ABB (Pisang Awak/Karpuravalli group) } \\
\hline $\begin{array}{c}\mathrm{T}_{4}-\mathrm{NRCB} \\
\text { Selection-10 } \\
\end{array}$ & 210.3 & 69.4 & 8.6 & 14.6 & 7.2 & 135.00 & 65.00 & 0.70 \\
\hline $\begin{array}{l}\mathrm{T}_{5} \text { - Budubale } \\
\text { (Check) }\end{array}$ & 352.3 & 64.3 & 5.4 & 11.2 & 7.8 & 123.00 & 51.00 & 0.50 \\
\hline $\mathrm{SE}(\mathrm{m}) \pm$ & 5.33 & 2.48 & 0.48 & 0.96 & 0.15 & 3.99 & 2.29 & 0.02 \\
\hline C.D. at $5 \%$ & 16.41 & 7.63 & 1.48 & 2.96 & 0.47 & 12.28 & 7.07 & 0.07 \\
\hline CV (\%) & 7.33 & 8.39 & 17.09 & 15.88 & 3.92 & 5.98 & 8.20 & 7.96 \\
\hline
\end{tabular}

Table 2: Performance of banana genotypes w.r.t yield attributes

\begin{tabular}{|c|c|c|c|c|c|c|c|c|c|}
\hline Treatments & $\begin{array}{c}\text { Bunch } \\
\text { weight } \\
\text { (kg) }\end{array}$ & $\begin{array}{c}\text { Bunch } \\
\text { length }(\mathrm{cm})\end{array}$ & $\begin{array}{c}\text { Bunch girth } \\
(\mathrm{cm})\end{array}$ & $\begin{array}{c}\text { Numbers of hands } \\
\text { per bunch }\end{array}$ & $\begin{array}{c}\text { Number of fingers } \\
\text { per bunch }\end{array}$ & $\begin{array}{l}\text { Yield } \\
\text { (t/ha) }\end{array}$ & $\begin{array}{c}\text { Finger } \\
\text { weight (g) }\end{array}$ & $\begin{array}{c}\text { Finger } \\
\text { length }(\mathrm{cm})\end{array}$ & $\begin{array}{c}\text { Finger girth } \\
(\mathrm{cm})\end{array}$ \\
\hline \multicolumn{10}{|c|}{ AAB (Plantain group) } \\
\hline $\begin{array}{c}\mathrm{T}_{1} \text { - BRS Selection } \\
\text { Popoulu }\end{array}$ & 16.7 & 52.7 & 160.1 & 7.5 & 67.4 & 41.75 & 264.6 & 18.2 & 20.0 \\
\hline $\mathrm{T}_{2}$ - Manjeri Nendran & 13.6 & 50.7 & 128.3 & 6.4 & 63.3 & 34.00 & 210.4 & 24.1 & 14.5 \\
\hline T3- Nendran (Check) & 10.3 & 40.1 & 101.4 & 5.7 & 55.2 & 25.75 & 190.2 & 22.3 & 13.4 \\
\hline \multicolumn{10}{|c|}{ ABB (Pisang Awak/Karpuravalli group) } \\
\hline $\begin{array}{c}\text { T}_{4-} \text { NRCB Selection- } \\
10\end{array}$ & 20.4 & 66.6 & 99.5 & 12.1 & 171.2 & 51.00 & 119.2 & 16.1 & 13.6 \\
\hline $\mathrm{T}_{5}$ - Budubale (Check) & 14.5 & 60.1 & 98.4 & 11.4 & 152.6 & 36.25 & 95.2 & 15.4 & 12.7 \\
\hline $\mathrm{SE}(\mathrm{m}) \pm$ & 1.48 & 3.17 & 3.56 & 0.37 & 3.09 & 3.69 & 3.24 & 1.01 & 0.47 \\
\hline C.D. at $5 \%$ & 4.55 & 9.77 & 10.98 & 1.14 & 9.53 & 11.38 & 9.99 & 3.10 & 1.45 \\
\hline CV (\%) & 19.57 & 11.74 & 6.06 & 8.60 & 6.07 & 19.57 & 9.63 & 10.48 & 6.33 \\
\hline
\end{tabular}

Table 3: Performance of banana genotypes w.r.t quality attributes

\begin{tabular}{|c|c|c|c|c|c|c|c|c|c|}
\hline Treatments & $\begin{array}{c}\text { Pulp } \\
\text { weight } \\
\text { (g) }\end{array}$ & $\begin{array}{c}\text { Peel } \\
\text { weight (g) }\end{array}$ & $\begin{array}{c}\text { Pulp to } \\
\text { peel ratio }\end{array}$ & $\begin{array}{c}\text { Days taken from harvesting to } \\
\text { complete yellowing }\end{array}$ & $\begin{array}{l}\text { Shelf life } \\
\text { (in days) }\end{array}$ & $\begin{array}{c}\text { TSS } \\
\left({ }^{\circ} \text { brix }\right)\end{array}$ & $\begin{array}{c}\text { Acidity } \\
(\%)\end{array}$ & $\begin{array}{l}\text { Reducing } \\
\text { sugar }(\%)\end{array}$ & $\begin{array}{c}\text { Total } \\
\text { sugar }(\%)\end{array}$ \\
\hline \multicolumn{10}{|c|}{ AAB (Plantain group) } \\
\hline $\begin{array}{l}\text { T}_{1} \text { - BRS Selection } \\
\text { Popoulu }\end{array}$ & 238 & 26.6 & 8.95 & 18.6 & 4.4 & 23.52 & 0.76 & 9.36 & 14.33 \\
\hline $\mathrm{T}_{2}$ - Manjeri Nendran & 167.3 & 43.1 & 3.88 & 6.2 & 3.0 & 26.74 & 0.18 & 17.15 & 20.31 \\
\hline \begin{tabular}{|l}
$T_{3}$ - Nendran (Check) \\
\end{tabular} & 148.8 & 41.4 & 3.59 & 10.8 & 6.4 & 25.13 & 0.34 & 11.51 & 15.82 \\
\hline \multicolumn{10}{|c|}{ ABB (Pisang Awak/Karpuravalli group) } \\
\hline $\begin{array}{c}\text { T4- NRCB Selection- } \\
10\end{array}$ & 99.1 & 20.1 & 4.9 & 3.0 & 3.2 & 20.73 & 0.14 & 14.07 & 17.25 \\
\hline $\mathrm{T}_{5}$ - Budubale (Check) & 76.8 & 18.4 & 4.17 & 5.0 & 3.1 & 20.42 & 0.16 & 13.08 & 16.35 \\
\hline $\mathrm{SE}(\mathrm{m}) \pm$ & 4.44 & 1.16 & 0.46 & 0.47 & 0.15 & 0.24 & 0.02 & 0.23 & 0.23 \\
\hline C.D. at $5 \%$ & 13.68 & 3.56 & 1.43 & 1.44 & 0.46 & 0.73 & 0.06 & 0.71 & 0.72 \\
\hline CV (\%) & 6.08 & 7.73 & 18.17 & 10.72 & 7.36 & 2.04 & 2.61 & 3.52 & 2.79 \\
\hline
\end{tabular}


Table 4: Economics of different genotypes of banana

\begin{tabular}{|c|c|c|c|c|c|}
\hline Treatments & Yield (t/ha) & Cost of cultivation (Rs./ha) & Gross income (Rs./ha) & Net income (Rs./ha) & B:C ratio \\
\hline \multicolumn{6}{|c|}{ AAB (Plantain group) } \\
\hline T1- BRS Selection Popoulu & 41.75 & 220000 & 417500 & 197500 & 1.89 \\
\hline $\mathrm{T}_{2}$ - Manjeri Nendran & 34.00 & 220000 & 340000 & 120000 & 1.54 \\
\hline $\mathrm{T}_{3}$ - Nendran (check) & 25.75 & 220000 & 257500 & 37500 & 1.17 \\
\hline \multicolumn{6}{|c|}{ ABB (Pisang Awak/Karpuravalli group) } \\
\hline $\mathrm{T}_{4-}$ NRCB Selection-10 & 51.00 & 220000 & 612000 & 392000 & 2.78 \\
\hline $\mathrm{T}_{5}$ - Budubale (check) & 36.25 & 220000 & 362500 & 142500 & 1.64 \\
\hline
\end{tabular}

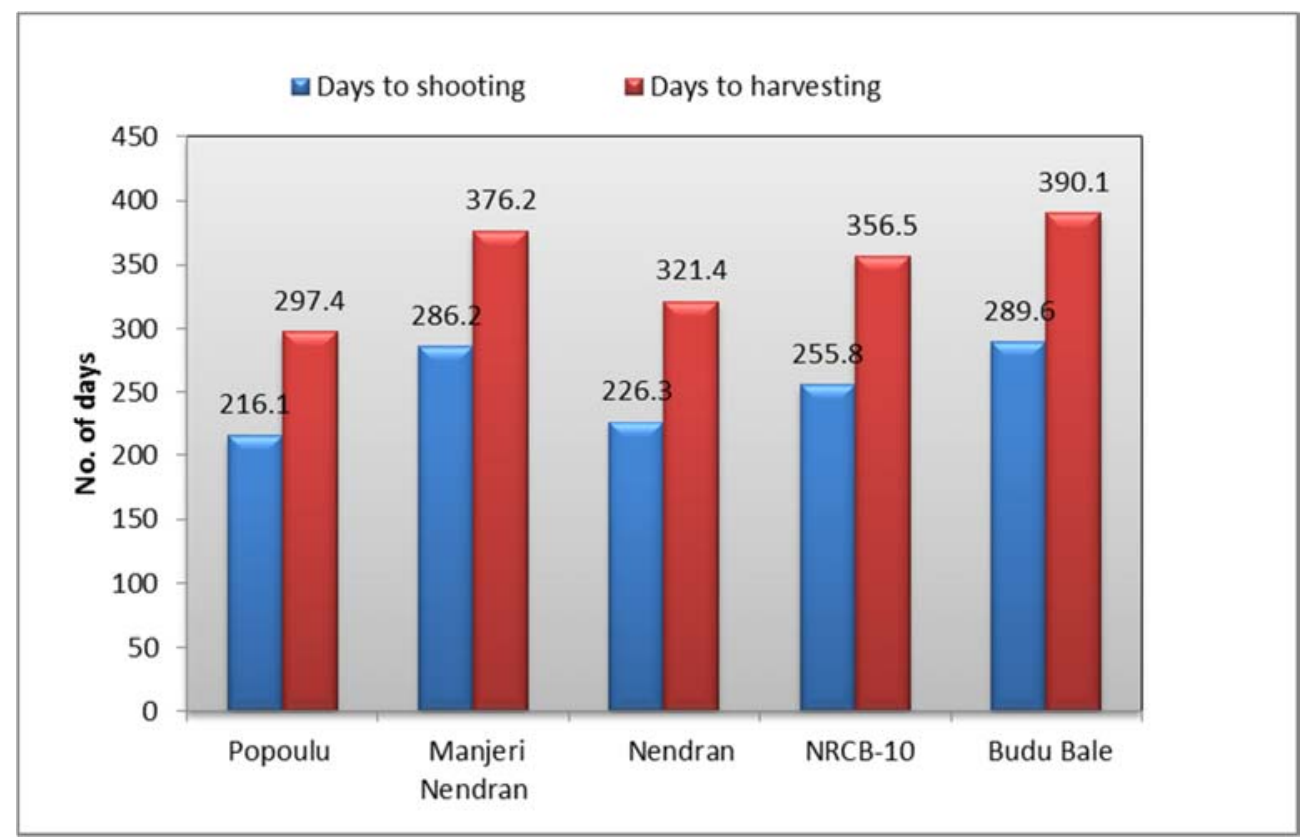

Fig 1: Crop cycle of different genotypes of banana

\section{Yield attributing characters}

It is evident from the data (table 3) that among all the genotypes, the bunch weight was highest in NRCB Selection$10(20.4 \mathrm{Kg})$ which was at par with BRS Selection Popoulu (16.7 Kg). The maximum bunch length was recorded in NRCB Selection-10 (66.6 cm), whereas, BRS Selection Popoulu recorded the highest bunch girth of $160.1 \mathrm{~cm}$. The new intoduction NRCB Selection-10 (ABB) had the highest number of hands and fingers per bunch i.e. 12.1 and 171.2, respectively. NRCB Selection-10 (51.00 t/ha) has superceeded to all other genotypes with respect to yield followed by BRS Selection Popoulu (41.75 t/ha) which were statistically at par with each other. Manjeri Nendran recorded the highest finger length of $24.1 \mathrm{~cm}$. However, the maximum finger girth $(20.0 \mathrm{~cm})$ and finger weight $(264.6 \mathrm{~g})$ were registered in BRS Selection Popoulu. The pseudostem girth, number of leaf retention and leaf area at shooting are important components for final yield. During the course of investigation, the result revealed that NRCB Selection-10 recorded highest number of hands and fingers which ultimately lead to highest bunch weight and yield among all the genotypes. Similarly, higher number of functional leaves and more leaf area at shooting might have contributed positively to higher yield in NRCB Selection-10. The highest finger weight $(264.6 \mathrm{~g})$ as well as girth $(20.0 \mathrm{~cm})$ in BRS Selection Popoulu makes it at par with NRCB Selection-10 with respect to bunch weight and yield in spite of the fact that BRS Selection Popoulu had lesser leaf area, number of hands and fingers than NRCB Selection-10. However, the differences in the genotypes with respect to yield attributing characters were controlled by genetic makeup of the genotypes. The results obtained in the present study with respect to yield and yield attributes corroborate with the results of Medhi (1994) ${ }^{[16]}$, Symal and Mishra (1989) ${ }^{[33]}$, Deo et al. (1999) ${ }^{[5]}$, Kumar (2000) ${ }^{[13]}$, Biswal et al. (2004) ${ }^{[2],}$ Deshmukh et al. (2004) ${ }^{[6]}$, Baruah et al. (2007) ${ }^{[1]}$, Njuguna et al. (2008) ${ }^{[20]}$, Kumar and Panday (2010) ${ }^{[11]}$, Rajmanickam and Rajmohan (2010) ${ }^{[22]}$, Suvittawat et al. (2014) ${ }^{[32]}$ and Menon et al. (2014) ${ }^{[17]}$. Kurian et al. (1985) ${ }^{[14]}$ reported strong positive correlation of fruit yield with number of hands, number of fingers, number of functional leaves per plant, girth of pseudostem.

\section{Quality parameters}

The data regarding quality parameters has been projected in Table 3. The values for pulp weight ranged between $76.8 \mathrm{~g}$ to $238.0 \mathrm{~g}$ and peel weight $18.4 \mathrm{~g}$ to $43.1 \mathrm{~g}$ among the different genotypes. Pulp to peel ratio ranged from 3.59 in Nendran to 8.95 in BRS Selection Popoulu. Higher pulp weight (238 g) and low peel weight (26.6 g) are desirable attributes for processing, which were observed in BRS Selection Popoulu. Peel weight was lower in the genotypes NRCB Selection-10 and Budubale. Higher pulp to peel ratio (8.95) was observed in AAB genome group cv. BRS Selection Popoulu indicating the pulp recovery would be high and is highly suited for preparation of chips. This is in line with the studies of Baruah et al. (2007) ${ }^{[1]}$, Ravi and Mustaffa (2013) ${ }^{[25]}$ and Menon et al. (2014) ${ }^{[17]}$. The total soluble solids (TSS) content of the screend genotypes showed significant differences. The maximum value for TSS (26.74 ${ }^{0}$ brix) was observed in the AAB group Manjeri Nendran and minimum value for TSS (20.42 ${ }^{\circ}$ brix) was observed in the ABB group Budubale. The 
genotype Manjeri Nendran recorded maximum reducing and total sugar of $17.15 \%$ and $20.31 \%$ respectively, whereas, minimum reducing (9.36\%) and total sugar (14.33\%) were observed in BRS Selection Popoulu. Stover and Simmonds (1987) reported that increase of TSS is an important trait of hydrolysis of starch into soluble sugars such as glucose, sucrose and fructose. Marriott (1980) ${ }^{[15]}$ indicated that a progressive increase in total sugar content and decrease in starch content was observed during ripening. This could be due to the hydrolysis of starch into sugar during ripening. These results are also in confirmation with the findings reported by Upadhyay and Tripathi (1985) ${ }^{[36]}$, Kanagaratnam and Theivendirarajah (1990) ${ }^{[8]}$, Rajamony et al. (1994) ${ }^{[23]}$ and Sarkar et al. (2005) ${ }^{[27]}$. A range of 3.0 to 6.4 days with respect to shelf life was recorded. Nendran (6.4 days) and
BRS Selection Popoulu (4.4 days) had better shelf life as compared to others. Intermediate values were recorded by Manjeri Nendran (3.0 days), Budubale (3.1 days) and NRCB Selection-10 (3.2 days) which were at par with 60 each other. Similar variations were also reported by Sarkar et al. (2005) ${ }^{[27]}$ and Uma et al. (2006) ${ }^{[35]}$.

\section{Economics}

Among all the genotypes, NRCB Selection-10 (ABB) recorded the highest benefit cost ratio of 2.78 followed by BRS Selection Popoulu of 1.89 (AAB) (Table 4). Delvadia et al. (2008) ${ }^{[4]}$ reported the highest benefit cost ratio of 2.77:1 in Gandevi Selection whereas lowest in Basrai (1.71:1). The present investigation is in similar trend with that of Delvadia et al. $(2008)^{[4]}$.

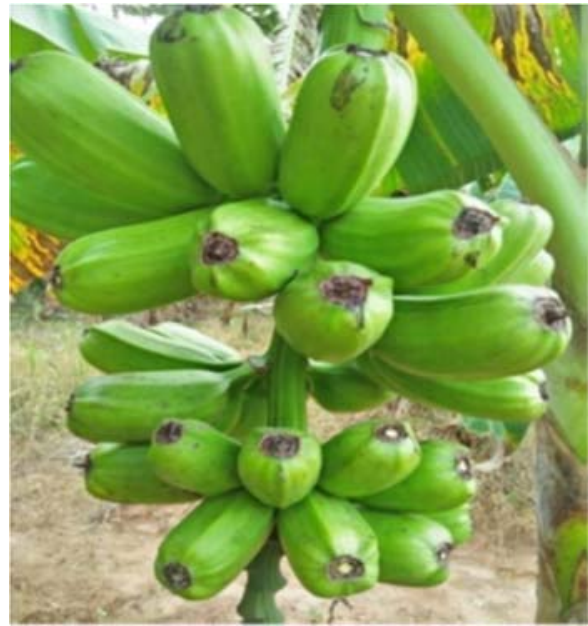

BRS Selection Popoulu

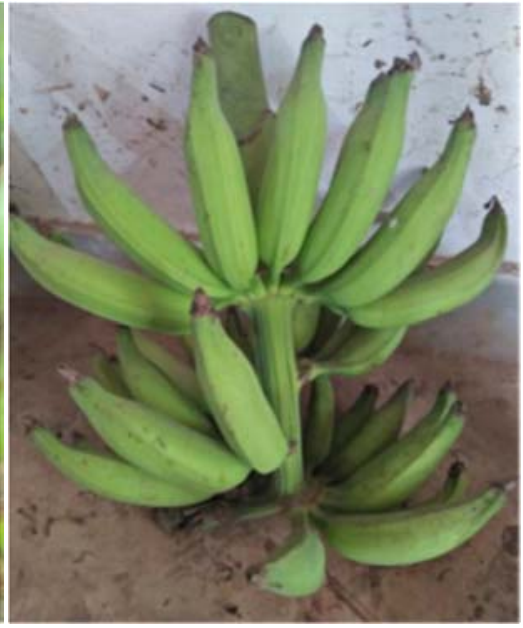

Nendran

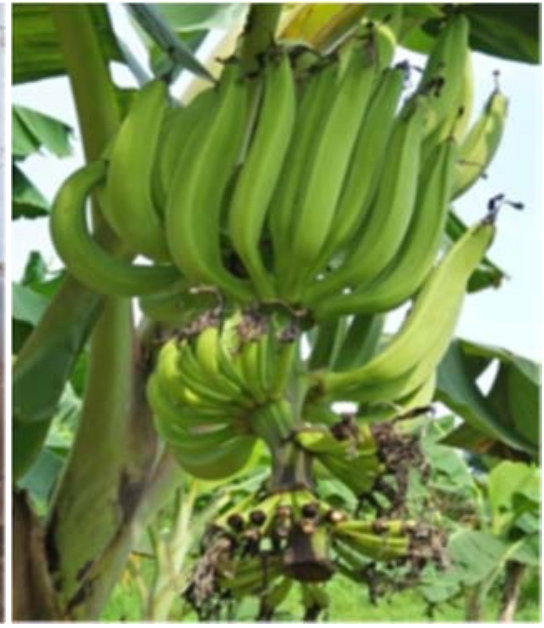

Manjeri Nendran

Bunches of AAB group genotypes

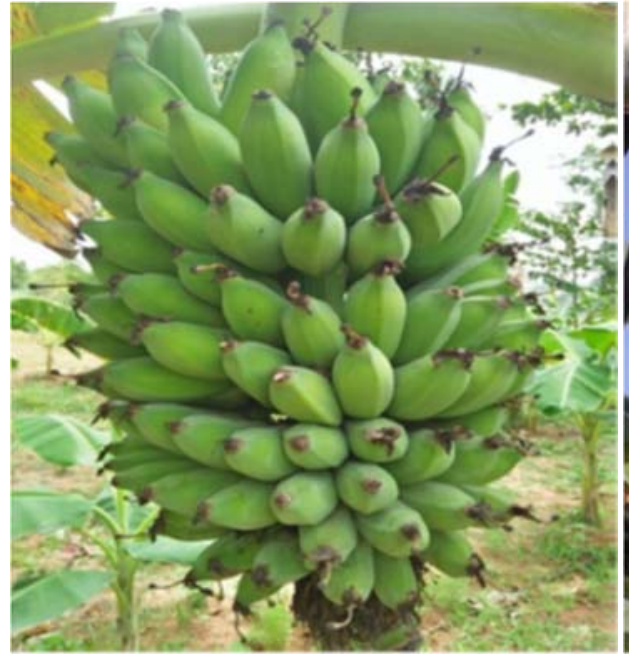

NRCB Selection-10

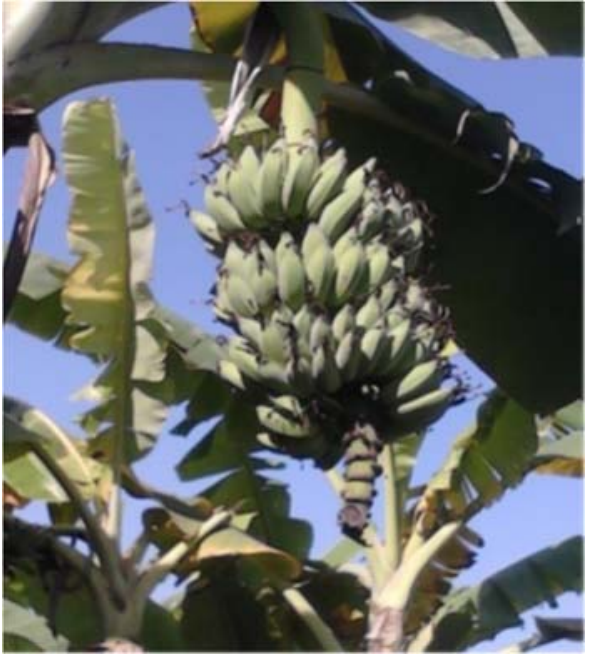

Budubale

Bunches of ABB group genotypes

\section{Conclusion}

The present investigation entitled "Evaluation of New Banana (Musa spp.) genotypes” generated useful information for selecting genotype suitable for Odisha conditions. The result indicated that among all the genotypes studied, NRCB Selection-10 proved its superiority in terms of yield and yield attributing characters with maximum net return. The above genotype also performed well recording the highest number of hands as well as fingers per bunch which was found in compliance with higher number of functional leaves as well as more leaf area. Fingers of this potential genotype showed ashy yellow coloured peel which resembles to Cheeni champa cultivar of Odisha. It has the potential to escape the damage due to heavy wind which can be attributed to its short stature 
and thicker stem girth. Keeping the above points in view, the genotype, NRCB Selection-10 may be recommended for commercial cultivation by the farmers. However, the traits like finger weight, finger girth and pulp to peel ratio was found to be highest in BRS Selection Popoulu which makes it at par with NRCB Selection-10 with respect to bunch weight and yield. Hence, it may be tried by the processing industry for preparation of chips.

\section{References}

1. Baruah K, Bhaskar, Sarma B, Sut D. Genetic variability in banana cultivars under Assam conditions, Indian Journal of Horticulture. 2007; 64(3): 282-285.

2. Biswal MK, Lenka PC, Dash DK. Evaluation of culinary banana genotypes, The Orissa Journal of Horticulture. 2004; 32(1):63-65.

3. Blomme G, Swennen R, Tenkouano A. Assessment of variability in the root system characteristics of banana (Musa spp.) according to genome group and ploidy level, Infomusa, 2000; 9(2):4-7.

4. Delvadia DV, Ahlawat TR, Chovatia RS, Barad AV. Performance of banana cultivars in Gujarat, Journal of Horticultural Sciences. 2008; 3(2):166-168.

5. Deo DD, Manohar VK, Sadawarte KT, Shelke BD. Growth and yield performance of banana (Musa paradisiaca) types under Akola conditions, Agricultural Science Digest, 1999; 19:278-280.

6. Deshmukh SS, Badgujar CD, Dusane SM. Comparative evaluation of banana varities under Jalgaon condition of Maharastra state, Agricultural Science Digest, 2004; 24(2):118-20.

7. FAO. Food and Agriculture Statistical Databases (FAOSTAT), In: http://apps.fao.org, 2009.

8. Kanagaratnam K, Theivendirarajah K. Studies on four cultivars of banana in the Jaffina peninsula, Srilanka, Vingnanam Journal of Sciences. 1990; 5:1-6.

9. Karuna Y, Rao KK. Studies on Phenological Characters of Different Banana Cultivars (Musa) in Visakhapatnam, Andhra Pradesh, International Journal of Science and Research. 2016; 5(5):1689-1693.

10. Kavitha $\mathrm{P}$, Balamohan $\mathrm{T}$, Veeraragavbathatham $\mathrm{D}$, Poornima K. Genetic variability and correlation in ecotypes of Nendran banana, Banana New Innovation Westville Publishing House, New Delhi, 2009, 91-98.

11. Kumar D, Panday V. Relationship of pseudostem cross sectional area with bunch weight, fruit quality and nutrient status in banana cv Rasthali (Pathkapoora-AAB), Indian Journal of Horticulture. 2010; 67(1):26-29.

12. Kumar D, Pandey V, Nath V. Growth, yield and quality of vegetable banana Monthan (Banthal-ABB) in relation to NPK fertigation, Indian Journal of Horticulture. 2012; 69(4):467-71.

13. Kumar R. Field evaluation of some culinary varieties of banana under subtropics of Bihar, Haryana Journal of Horticulture Sciences. 2000; 29(3 \& 4):138-39.

14. Kurian TM, Prabhakaran PV, Varkey PA. Path coefficient analysis in Nendran variety of banana, South Indian Horticulture. 1985; 33(1):386-89.

15. Marriott J, Robinson M, Karikari SK. Starch and sugar transformation during the ripening of plantains and bananas, Journal of Science, Food and Agriculture. 1980, 1021-1026.

16. Medhi G. Performance of some cultivars of Banana (Musa paradisiaca) in Assam, Haryana Journal of Horticultural Sciences. 1994; 23:181-85.
17. Menon R, Nair S, Suma A, Manju PR, Cherian A, Patil P et al. Introduction, evaluation and adoption of an exotic banana (Musa AAB cv 'Popoulu’) (EC320555) to Kerala, India, Indian Journal of Plant Genetic Resources. 2014; 27(3):298-302.

18. Ngalani JA, Tchango JT. Cooking qualities and physiochemical changes during ripening in some banana and plantain hybrids and cultivars, Acta Horticulture, 1998; 490: 571-76.

19. NHB. 2016-17. http://nhb.gov.in/area\%20_production.html.

20. Njuguna J, Nguthi F, Wepukhulu S, Wambugu F, Gitau $\mathrm{D}$, Karuoya $\mathrm{M}$ et al. Introduction and evaluation of improved banana cultivars for agronomic and yield characteristics in Kenya, Africian Crop Science Journal. 2008; 16(1):35-40.

21. Purseglove JW. Musaceae. In Tropical Crops. Monocotyledons John Wiley and Sons, New York, 1975, 343-384.

22. Rajamanickam C, Rajmohan K. Variability studies in Palayankodan ecotypes (AAB genomic group) of banana (Musa spp.), Journal of Hortultural Science. 2010; 5(2):109-13.

23. Rajamony L, George KC, Anitha N, Radhakrishnan TC. Assessment of banana (Musa x paradisiacal) clones of $\mathrm{AAB}$ groups based on stability and adaptation, Indian Journal of Agricultural Sciences. 1994; 64(8):521-26.

24. Ram RA, Prasad J, Pathak RK. Studies on the performance of different culinary cultivars of banana, South Indian Horticulture. 1989; 37(5):296-97.

25. Ravi I, Mustaffa MM. Starch and amylose variability in some banana cultivars, Indian Journal of Plant Physiolog. 2013; 18(1):83-87.

26. Sanchez NF. Effect of zone and climate on yields quality and ripening characteristics of Montecristo banana grown in Puerto Rico, Journal of Agriculture University of Puerto Rico. 1971; 54(2):195-10.

27. Sarkar SK, Bauri FK, Misra DK and Bandyopadhyay B. Varietal evaluation of silk mysore and pome sub group bananas for yield and post-harvest attributes including diseases and pests, The Orissa Journal of Horticulture. 2005; 33(2):20-24.

28. Simmonds NW. Bananas Longmans, Green and Co. Ltd. London, 1959, 250.

29. Simmonds NW. The evolution of bananas, London: Longman, 1962, 170.

30. Singh J. 'Basic Horticulture', Kalyani Publ. Ludhiana, 2002, 6

31. Stover RH, Simmonds NW. Bananas. 3rd Ed: John W \& Sons Inc: New York, 1987.

32. Suvittawat K, Silayoi B, Teinseree N, Saradhuldhat P. Growth and yield of eight 'Namwa' (AAB) Banana in Thialand, Acta Horticulture, 2014; 1024:241-46.

33. Syamal MM, Mishra KA. Studies on some dessert banana (Musa sapientum L., Indian Journal of Horticulture. 1989; 46:316-18.

34. Uazire AT, Ribeiro CM, Mussane CRB, Pillay M, Blomme G, Fraser C et al. Preliminary evaluation of improved banana varieties in Mozambique, African Crop Science Journal. 2008; 16(10):17-25.

35. Uma S, Saraswathi MS, Sathiamoorthy S, Durai P, Natarajan R. Evaluation of indigenious and exotic banana (Musa spp.) hybrids for subsistance cultivation in India, Indian Journal of Agricultural Science. 2006; 76(12):747-49. 
36. Upadhyay NP, Tripathi BM. Studies on some dessert banana (Musa paradisiaca L.) cultivars, Progressive Horticulture. 1985; 17: 91-94.

37. Von Leosecke HW. Bananas Interscience publishers, INC New York, 1950. 